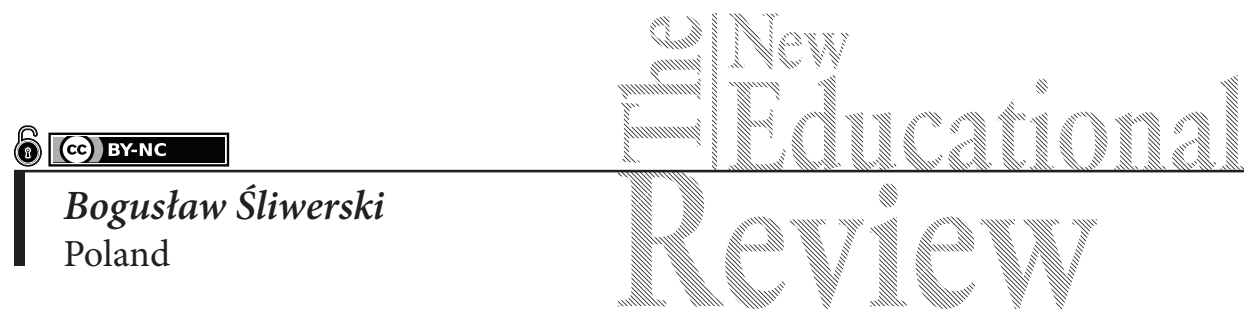

\title{
The Polish Educational Policy after 28 Years of Political Transformation
}

DOI: 10.15804/tner.2018.52.2.12

\begin{abstract}
In this article I make a critical analysis of educational policy in Poland during the 28 years of the political transformation. In the transition period in Poland, from 1989 to 2017, education did not become a source of ongoing changes in the country. Further formations of political power, selected through elections, instead of decentralizing the school system, allegedly led to the creation of new models of school in a corset of centralism. To make matters worse, the prime ministers of the following governments from different political parties, taking into account their own or party interests, created the ministry of national education (or their decision-making power apparatus) who had disturbed communicational relationships with the public. In this article, I explain the reasons for the betrayal of elites in the context of fundamental assumptions of the "Solidarity" movement in the years of 1980-1989. As a result, Polish society abandoned the deliberative and participatory democracy. I look at how education, as a science and practice of education, fits into democratization of the Polish state and society. What is of key importance is the perception of education as a common good, as environments and entities, institutions or management practices which participate in a democratic society.
\end{abstract}

Keywords: educational reforms, educational policy, critical pedagogy, school, democracy, contradiction, educational perpetrators, educational policy 


\section{Introduction}

The political transformations initiated in Poland in 1989 enabled a change of the state's political system, including (also educational) administration. The question was raised, then, whether (and if so - to what extent) it would be possible to elaborate and present a coherent and complex concept of the Polish education system in its final shape. It is difficult to reform education if, within the state of relatively modern but quasi-democratic authoritarianism, there is no well-organized and efficient system of education, which would remain under social control and public administration service above the level of political parties. Without decentralization and independence of school education as well as without its society-based management, Polish education will not get out of its deeply rooted remnants of "homosovietism" and will not be able to construct modern and effective teaching and moral education of young generations of Poles. Such an education will not take up the challenges of post-modernity, as the paternalistic role of the state in the educational policy draws back social and individual development by the participation of education, although the next political reform is implemented under the apparent care for children's good.

\section{Analyses of the political transformation commencement}

Undertaking an analysis of the early years of the transformation towards a democratic country and free market economy in the Polish People's Republic, Edmund Wnuk-Lipiński, a sociologist, was fully aware of the lack of theoretical models for conducting social studies in this field (Wnuk-Lipiński, 1996). Therefore, sociologists had to apply some available analytical models, out of which each allowed for capturing the typical - of this system of determinants - processes and mechanisms occurring within it as well as their consequences. The totalitarian model enabled the description and explanation of the socialist system in macro-political categories. The structural-functionalist model completed the knowledge concerning the institutional role of the authorities and social structures in the process of taking political decisions. The model of political culture facilitated studies of citizens' attitudes and behaviour patterns in a totalitarian state, whereas the developmental model oriented researchers towards its evolving, depending on economic, social, etc. changes. Pluralistic models, as the antinomies of some models of totalitarian states, were useful for noticing various groups of interests, for the development of corporationalism, local authorities, etc. Finally, the bureaucracy model allowed for 
explaining the functioning of the administration apparatus and the structures of political rule in the state, while the model of the "patron-client" relation enabled taking into account in social diagnoses the phenomena associated with reaching the ruling power and developing (within it) various influences, paternalism, corruption, nepotism, etc. (ibid., pp. 17-18).

In the early 2000s, while I was taking part in some team studies concerning teachers in post-communist countries as victims and perpetrators of manipulation, researchers had to elaborate theoretical assumptions for the diagnosis which would allow them to verify their state of attitudes and experiences as a hypothetical remnant of the homo sovieticus syndrome (Wróbel (ed.), 2010). At that time, we reached for two theoretical models for diagnosing and interpreting teachers' attitudes in Poland, the Czech Republic and Slovakia - the psychological theory of manipulation (Cialdini, 1996; Grzywa, 1997; Joule, Beauvois, 2006; Wróbel, 2006) and Jürgen Habermas's philosophical theory of human rationality (as cited in: Kwaśnica, 1987). If we had wanted to examine teachers' level of engagement in educational changes, innovativeness or creativity, we would have had to reach for different theoretical foundations, which would have allowed for a proper interpretation of empirical data. However, the set of available theoretical models was limited, because the process of transformation, resulting from the grassroots but peaceful revolution, did not find supporters of its exploration within pedagogical sciences. In the debate on the research results, Monika Popow rightly indicated that what could be used for the analysis of macro-political determinants of teachers' work after the political transformation were the assumptions of post-colonial pedagogy, which undertook the emancipation of teachers in the school system (Popow, 2010).

Therefore, researchers' interest was in "decolonization of teachers' minds", until recently dominated by the practices of totalitarian rule. This was aimed at studying the feeling of objectification and of being manipulated or of conscious self-effectiveness or co-effectiveness in manipulating others. "Thus, postcolonial teachers have the task to deconstruct the concepts of eternal fight between various groups - normal citizens and social pathology, the governing and the governed, winners and losers" (ibid., p. 53). In the post-socialist state, teachers should take active part in the process of transformation towards democracy so that both learners and their parents can recognize the possibilities of participation in co-deciding about the quality of kindergarten and school education as well as become active actors in these processes.

While diagnosing teachers' level of adaptation (submissiveness, being a victim of manipulation) or emancipation (sovereignty) on a sample of 376 people 
working in all types of schools and with different degrees of career promotion in three post-communist countries, it turned out that: “(...) $12 \%$ of teachers presents $0-20 \%$ of manipulative behaviour patterns. Among the vast majority of teachers (70\%), manipulative behaviour patterns constitute $20-40 \%$ of all the behaviour. Teachers whose majority of behaviours consists of manipulative behaviour patterns constitute 15.2\%" (Śliwerski, 2010, p. 247).

It was possible to diagnose a significant interdependence between teachers' manipulative behaviour patterns towards learners and all the indicators of job burnout. It turned out that, e.g., the higher teachers' level of job burnout was, the more intensive tendency to manipulation they had. It would be very interesting to find out to what extent teachers present submissive attitudes in relations with educational supervisors or learners' parents, in which teachers become victims of their manipulation. This only confirms that the educational environment is affected by market - but antagonistic - competition, resulting in the fact that: "their common fate was exposed at the mercy of an impetuous game of market powers, making the lack of long-term economic and social policy the only policy" (Szahaj, 2014, p. 17). In the neoliberal state, people are discouraged from citizen activity and youth is socialized into faking it. My studies on the lack of socialization of school education, including children and youth, clearly confirm the breakdown and deep crisis of citizen education (Śliwerski, 2013).

\section{Lack of democratization in the school education of the Republic of Poland}

In the light of my research, carried out for 28 years, into democratization of public education, it can be confirmed that Poles still live in a centralized state. What is still active in this state are some parts of the ruling elites (aptly called by Leszek Balcerowicz the "soviet activist"), who keep making the law that have remained from the previous system, but the former models of centralism have been replaced by statism, kept hidden by the authorities (Śliwerski, 2013). The period of socialist statehood must have consolidated the tradition of hostile attitudes to state authorities among Poles for many years. Yet, among a large part of the pedagogical environment, it also enhanced the feeling of omnipotence (e.g., ideological categories: teachers - nation's educators, or legal categories: pedagogical sovereignty), of the superiority of ruling authorities and institutions over the people they should serve.

When looking back and postponing, at least for a while, one's own interests, animosities and ideological or axionormative differences, it can be noticed that 
the school system in the Third Republic of Poland (III RP) has not been subjected to a deep and politically (in the constitutional and statutory pro-democratic - for education - sense) intentional reform. This results from the elimination by the consecutive ministers from the process of change of the answer to the fundamental (for the type and size of the changes) question of general political nature: Why is the school system not subjected to democratizing (socializing) processes but has had to and will still have to keep the status quo - to stay within the state's disguised unfulfilled political prerequisites and the assumed functions of Polish education? This process of conservation in education and with its participation of different types of despotic rule, its monopolizing inner "hardware" reforms (infrastructural ones - ownership relations, economy, management, equipment) and "software" reforms (Heliodor Muszyński’s term), which comprise the curriculum, social relations (untouchable hierarchy and authoritarianism, the antagonized teachers' environment, e.g., by the system of career promotion, penitentiary nature of pedagogical supervision, etc.) and non-participatory cooperation of all actors of education, make society totally disoriented. This takes place within chaos and mutually exclusive solutions, inadequate to the state of knowledge concerning the development of children and youth or the methodologies of their education.

It is not without significance whether educational, transformational reforms are made with the main actors of the change or against them or one of them. As my analyses of the state's educational policy over the last twenty five years show, it is not possible to change school and its educational process if the boundary, system-wide conditions of its functioning are from a different political epoch and culture. Undoubtedly, it is possible to consume individually or institutionally the so-called material aid for school education by feigning changes and by their fragmentary exemplifications, which appear and disappear along with the inflow or its lack of financial resources from the EU. Yet, this does not substantially affect the developmental prospects of education that precede what is taking place "here and now". The EU resources pumped into education improve only the material condition of their beneficiaries, mostly project contractors, but they do not enhance the activation of self-regulative, self-creative and innovative processes, because as regards the system - it still involves supervision and control, standardization and limitation of the activity of subjects responsible for the quality of education.

Even the project of educational leaders or leadership crashes against the glass pane of bureaucratically executed authoritarianism, which allows the educational authorities to use the school system to manipulate society. The fundamental cause of this status quo is the educational macro-policy of the Polish state, which involves control of business and educational authorities acting as a corporation 
pyramid. It is not surprising that those drawing the profits at the top would not give them up on their own. This is not what they aimed at while climbing for power. For the system of school education, the effects of resigning from a system reform of education as supplementation of the state administration reform were the following:

- maintaining the dualistic public administration, with its division into government and local authority. With the lack of consensus and a coherent common strategy and tasks for both organs, this brings about unceasing conflicts and a counterproductive policy concerning educational management, executing pedagogical supervision by local authorities (organs running educational institutions). It should not be surprising that the educational policy is not coherent and uniform, especially in the regions where government and local authorities are from opposing political formations;

- partial decentralization of tasks and competences towards local authorities but resulting in a war between the territorial administration and government, triggered by increasing tasks and decreasing subventions for them.

Procedural democracy does not allow for distinguishing between democratic and non-democratic systems as it is limited democracy or pseudo-democracy that are situated between the two. An educator can take one of the three positions in the antagonized political world - being an enemy, ally or someone neutral in the relations between the authority and society. It is quite natural that the authorities will strive for allies and people not engaged in the natural social conflict, but fight against enemies. Teachers, as neutral subjects, are important for the authorities only as much as they can be transformed into enemies or allies. This explains the situation which took place after changing the political system in Poland in 1989, as a result of which the educational authorities stopped being interested in teachers as neutral subjects of education.

At first, the authorities acted in such a way in order to free the autonomy of teachers, learners and their parents as well as to create the foundations for the grassroots process of socializing public education and to strengthen participatory competences of all these subjects in the process of co-deciding about educational quality at schools and transparent solving all problems and conflicts during the course of school education. However, after the return, in 1992, of post-socialist political powers (also in education), which were explicitly hostile to democratization and self-governance, the antagonistic relations of educational authorities and representatives of the scientific world were introduced to the political arena and got consolidated there. From that moment, the ruling authorities were interested in the restitution of a totalitarian state and in maintaining a centralized educa- 
tion system. In order to co-manage this system, the focus was on teachers-allies, mostly from neo-leftist or later neo-conservative formations, completely ignoring and disdaining the essentially neutral but critically engaged teachers. They were defined as enemies of the ruling authorities, which - in an unceasing political conflict - needed nothing but allies.

Unfortunately, what still exerts influence in Polish society is the myth of conflictlessness, avoiding or hiding conflicts so that the rulers would not have to justify their decisions. Yet, such an attitude is typical of totalitarian or authoritarian, not democratic, states. An educator as an enemy in democracy is treated as an alien, who is either tamed, pacified, isolated, stigmatized, excluded, or whose views or research results are maximally neutralized. In the education system, such teachers enter the non-public sphere, where they can keep their sovereignty - though even there this takes place at the cost of a certain piece of this sovereignty.

\section{The position of science in the policy of educational transformations}

What should not be practiced is escaping from politics, just the opposite - one should engage in or strengthen the movement of radical change projects which would refer to democracy and the common system of values not to enable the solidification of the political scene of the state and the constant and treacherous manipulation of citizens by the ruling "sly dogs". In the politics created in this way, people become a means for achieving aims, only apparently taking into account their needs and respecting their rights. It is necessary to revalue all values into the new counterculture movement to prevent the consolidation or advancement of the ideology of merciless social Darwinism.

Not without fault are here the representatives of humanities and social or economic sciences, a part of whom have drifted away from the humanistic sources, being infatuated with mathematical models and the pressure of quantitative approach to (not only economic) phenomena associated with the transformations in the III RP. This is known as the process of categorization, evaluation, accreditation and parametrization of the sphere which might be approached in the model (idealization) way but in reality is very distant from it. "Ignoring the complexity of social life and of the humanistic dimension in economy resulted in previous years in expanding arrogance of some economists, especially all kinds of economic experts (mostly of neoliberal and libertarian origin), who lectured their truths as the obvious in the way that allowed no objection and with evident 
disdain for those who had a different standpoint and a long time before had warned of the approaching crisis" (Szahaj, 2014, p. 54). What can be seen, with growing accuracy, in education is that the problems of the Polish school system and education of the young are adjusted by state authorities to political interests and goals of international global economic organizations (OECD, World Bank). This can be exemplified in the best way by financing from the state budget the political monitoring of the apparently scientific studies on 15-year-old learners' skills and knowledge (PISA programme) and even on other age groups of Polish society (Śliwerski, 2016). Greed, cynicism, meanness of rulers can be seen in the distribution of EU resources for development, within such programmes as, e.g., "Human Capital".

It is painful that the elites of the Third Republic of Poland have violated the elementary principle of justice by letting the perpetrators of socialist totalitarianism in Poland remain unpunished, by not getting even with the executioners of those times. "Society received a demoralizing signal: no matter what you do in life, if you keep with the stronger, with those who ensure protection and support, you can expect success (...) The beneficiaries of the new system were mostly those who had been well also in the old system. The material success of the representatives of "the only right force" did not result from extraordinary ability or heroic diligence but from the so-called deals and contacts, which turned out to be the most precious economic capital in the new times (many people talked about solidarity so they acted in "solidarity"). Unfortunately, the lesson of "getting of the guilt" and the later success of post-communists has demoralized also the other side of the political arena" (Szahaj, 2014, pp. 72-73).

After 28 years of liberty, demoralization enhanced by the system is still present. A. Szahaj understands this as breaking the fundamental principles of the state of law, democratic state, which is gradually appropriated by interest groups which achieve success owing to certain social arrangements, the access to the office-political and business class, nepotism, bribery, and dishonesty. The demoralization of political classes co-occurs and is supported by treachery of clerks - the part of elites which hope for quick wealth owing to their servile attitude to the authorities. The ruling powers disdain, marginalize, undermine the opinions of critics who do not tolerate the transfer of public money to private hands. What is even worse, "(...) academic scholars and intellectualists have disappointed as well, letting themselves believe that without personal wealth they mean nothing, so they took to collecting it with energy, finding neither time nor will to participate in public life; we have all disappointed, being busy with our private matters, ignoring the public sphere, forgetting about a republican principle that good life 
requires good society - and this can only be achieved when the care for one's own good is combined with the care for common good. By turning away with contempt from politics, we have paved the way for people who have turned out not worthy of our trust" (Szahaj, 2014, p. 79).

\section{Pedagogy as a servile science}

Ever since its beginning, pedagogy - due to its assumed function - has been a part of the sphere of public affairs and goods, associated with the rule of people, institutions and environments over the learning generation, which participates in educational and socializing processes. It is impossible not to refer here, particularly today - in the period of assessing the role of pedagogy in the socio-political transformation of the III RP, to the issue of democracy and its relations with educational sciences and didactic craft. Examining the relations between pedagogy and socio-political processes should be of crucial significance, because without revealing them, without appropriate recognition of their essence and the scope of influence (or its lack) it is not possible to answer the question concerning the direction for which Polish education heads. Therefore, it is necessary for researchers to undertake further macro-political studies of the ruling processes in Poland, including those within education and aimed at it in order to leave Plato's cave of ignorance and helplessness.

Across all the consecutive political formations governing the state, educators as well as representatives of other social sciences in Poland have not used the transformation time which they were offered for strengthening grassroots initiatives and the simulation or protection of socialization processes of the Polish school system and higher education. Education has become an inhibitor for Polish democracy and the authorities of the Ministry of National Education have done their best to ruin the efforts of parents and some teachers and scientific environments aimed at transforming school and introducing into kindergartens not feigned collaboration for the common good. The authorities discourage educational subjects from their authentic participation in decision making processes, in shaping the educational policy, citizen dialogue and social engagement. The freedom regained by the nation is not given to it for ever. If people want not only to defend but also to consolidate the regained liberties, they - as a society - have to withhold the possibility of violating them, also by the authorities, by civil counterbalance.

What has not changed since the fall of socialism is the situation of educational experts in their relations to the group that makes decisions concerning the 
implementation of the planned educational change in the Polish school system. Against the statement that it has a public character, in fact the system is still a centralistic structure with a hierarchical organization of rule (supervision). The relations between scientists-experts and the authorities were already focused on in 1987 by Zbigniew Kwieciński, who distinguished three categories: 1) experts who constitute a part of the environment and have been invited or summoned to cooperate (including full time staff of the informational and executive background of the central authorities or some outer specialists treated by them as professional authority), 2) independent specialists, developing the knowledge of education and its changes for the good of education itself, science and society, not for the use of the authorities, 3) critical experts, who in public provide their opinions on the reformers of the centralistic rule and indicate its errors, dysfunctions, pathologies, or who point at the possibilities of alternative reforms, more efficient and functional for the interests of certain large group, or who make attempts to understand what is going on, what has occurred, why and with what effect (Kwieciński, 1987).

Educators who adjust their models, projects or offers to political manipulation with law are servants of political social engineering, they do not serve the essence and quality of the educational process. Often against their own declarations about recognizing multitude and pluralism in the world of ideas, scientists serving political interests of the authorities become fundamentalists, apologists of a one-sided vision of reality, which excludes the existence of any other reality. Such an attitude may co-occur with blindness, fanaticism or fervency of the engagement in the only right matter, its promoting and fighting against different ideas. If a political subject is the one who uses the measure required by the current arrangement of powers (someone ready to use anyone to achieve their goals), education - along with pedagogy as a science - can be subordinated to these requirements and be summoned to fight in the public space.

Pedagogy servile to centralistic authority is a kind of pedagogy which instrumentalizes a human being, whose dignity is manifested in being only a means and a certain instrument or "thing" for achieving others' goals. By creating educational reality in an antagonistic way, such a pedagogy will aim at influencing this reality from the only right and valuable, one's own paidagogia, no matter whether someone notices, understands and accepts this or not. Its essence is making people dependent, committed to promoting it, making them join the struggle against any other pedagogy, not collaborating with it. Therefore, pedagogy in service becomes also a media and marketing product of contemporary times. It generates its own authorities and ridicules or depreciates others. If educators are unable to persuade 
others what they need and why this must agree with their ideology, they will cynically create such needs and expectations with the use of social engineering and political manipulation. If such a strategy turns out not to be effective enough, they will start a negative offensive, consisting in triggering fear, anxiety, fearful visions of what can happen if their ideology is not implemented in education. Fascination with effectiveness and the instrumentalization of the indicated goals results in pedagogy not noticing its "counter-effectiveness" - if achieving particular goals is excessively wanted, the opposite is achieved in fact. The servile nature of pedagogy as an element of spiritual culture of modern civilization leads to barbarianism by destroying and degrading culture, by decomposing people's attitude to the world of values. Such a pedagogy will always be statist, ideological, subordinated to the interests of the ruling political parties.

\section{Pedagogy of social service}

Building pedagogy of social service is based on the counterpoint principle such a pedagogy has to indicate the black side of the opposing pedagogy to evoke objection, rebellion, discord towards it in order to threaten with potential, thus unverifiable here and now, results of its further functioning in society. This pedagogy needs to trigger fascination with itself and rebellion towards any other, so that all other pedagogies will fall down, become absent, disappear from the scene. It is not possible to be in two systems of ideological reference to pedagogy as this reveals the paradox of human functioning, of being inside and at the same time outside a particular ideology. Pedagogy in service gets limitlessly subordinated to every rule, regardless of its ideology. It is a kind of servile, submissive pedagogy which resigns from its own autonomy.

Researchers should not sell their soul to the devil and undertake action in the name of political correctness or individual aims. This ethical imperative concerns particularly them as they can read and understand, much better than other citizens, the discourse of the authorities which steer society not always for its good. This is even more important now, when politicians' lies are more and more frequently hidden with the help of subtle public relations techniques - with the use of scientific knowledge. A lie in politics is intentional in the same way as not noticing it by scientists - if they do not reveal it to society, they support the destruction of both the public sphere and democracy to the same extent as its perpetrators. Unaware of the threats on the part of the authorities, citizens experience not only personal but also social loss, because their sensitivity to 
dysfunctions and pathologies (developing due to ignoring their real sources) is being suppressed. This sensitivity is a sine qua non for existing in the public sphere in citizen society.

Educators, as neutral subjects in education, who do not impose their standards or research results to make the public debate or decisions their hostage, do not function in the public space, in the educational process, as subjects with the feeling of rightness and moral superiority. Such an educator is someone who is guided not only by their own interest but also by the feeling of the moral value of an act in order to testify the truth. It is much easier to meet such attitudes in deliberative democracy. In the times of brutal intervention of political and economic interests, the need for protecting humanity, its dignity and culture is of crucial significance. Pedagogy of social service should make people aware of the contamination of human minds with falsehood or criminal ideas, it should detoxify human consciousness by unmasking falsehood, bad intensions, ignorance, dehumanizing theories. Such a pedagogy ought to enhance an awareness open to liberty, truth, democracy, good and tolerance, to regenerate the world of social and citizen values, to evoke human conscience and responsibility for one's own and others' life. It is a necessity here to protect a person as a free and sovereign being in relation to society/the state, which is also a sovereign and works for common good.

The role of modern pedagogy of social service should consist in bringing back to life a public human, and - in this way - in the return to building a civil society. Both these categories are destroyed by the ruling group. They do their best, with huge EU financial resources for promotion (social campaigns, locating ideas as products in media) and public relations specialists, not to let content-based arguments clash in the public debate and to substitute this debate with the "stardom system" in empowering the authorities' decisions. The more opposing the authorities' standpoint is (both in terms of public interest and scientific arguments), the more frequent and stronger use of the methods and means of political propaganda takes place - often with the support of celebrities, including some scientists, obedient to this strategy of the rulers. In this situation, educationalists need to join the tackling of numerous myths, constructed and disseminated by the authorities, as well as meaningless statements (announced by intellectual stars), which draw society's attention away from many important dangers and damage to which the government's technocratic politics leads.

Like the underground resistance movement against the totalitarian rule in the People's Republic of Poland, today - in the state with a quasi-democratic school system, there is a new agora. It is a world of virtual protest, parallel to the real 
world of the authorities' manipulation, which has the nature of a rhizome and a hyper-text and non-physical structure of the network of interpersonal relations that report the expression of differences from the position of outsiders demystifying the lying and hypocrisy of the ruling authorities. They shift the moral awareness of the elites to make them collaborate apparently within educational modernization and reforms and, in fact, to undertake actions contradicting the values they should serve. Thus, what might be a mistake of educational elites is seeking the chances to join school reforms and the improvement of Polish education within the areas (defined by arrogant and incompetent authorities) of possible activity so that it will not infringe the authorities' hidden interests which are - as a result of undertaken decisions - contradictory to the national interest.

\section{Conclusions}

In a democratic state, intellectuals should blow up the stereotypes and solutions which limit human sovereignty and public communication, resist and express the fears, views, feelings or opinions of those who fear the consequences of their own courage. A critical educator should take the position of an "uninvited outsider", independent from the expert's authority, who will question the imposed appearance and falsehood, reveal "the kiss of death from the establishment" acting for the collaboration with the rulers despite considerable differences of standpoints. In the opposite case, by keeping silence, educators accept the state of growing pathology and become its co-perpetrators. In erosion affected democracy, this becomes a consent to develop politically correct nomenclature, which can be fought against only by opposing the attempts to pack the elites into the framework of the authorities' interests. It is impossible to change the existing pathology by participating in its processes in collaborative activity.

What seems necessary is breaking the consensus machinery to stop citizens' indifference. Unfortunately, some educationalists, psychologists and, in a growing number, sociologists have been degraded (of their own will) to submissive attitudes by yielding to the neoliberal authorities and providing them with selected thus manipulated - transformations in the last decade. This is the reason why the authorities overuse the terms "collaboration" and "good practices", washing them away of their right sense, giving them the meanings which slyly hide the truth instead of undertaking actions aimed at genuine transformations. Therefore, what should be the role of pedagogy is equipping society with theoretical tools so that 
it could understand the processes which take place within it and with infringing its interests.

Several decades have passed of reliable studies in critical pedagogy. The time has come to broaden the knowledge of macro-political determinants of the educational policy of post-totalitarian countries, reaching for, e.g., an emancipatory, anti-authoritarian and critical pedagogy. Educators ought to stop being co-perpetrators of pretending democracy and destroying self-governance by consecutive elites of political authorities in the world full of hypocrisy and political lies.

Translated by Agata Cienciała

\section{References:}

Cialdini, R. (1996). Wywieranie wpływu na ludzi. Teoria i praktyka (Influencing people: Theory and Practice), Gdańsk: GWP.

Grzywa, A. (1997). Manipulacja. Mechanizmy psychologiczne (Manipulation. Psychological Mechanisms), Kraśnik: Wyd. Graf.

Joule, R.V., Beauvois, J.L. (2006). Gra w manipulacje. Wywieranie wpływu dla uczciwych (Small Treatise About Manipulation of Honest People), Gdańsk: GWP.

Kwaśnica, R. (1987). Dwie racjonalności. Od filozofii sensu ku pedagogice ogólnej (Two Rationalities. From Philosophy of Sense to General Pedagogy), Wrocław: IKN.

Kwieciński, Z. (1987). Wspólnota złudzeń reformatorów oświaty i ich ekspertów (The Common Illusion of Education Reformers and Their Experts) [in:] preprint referatu z konferencji naukowej "Badania oświatowe a polityka oświatowa" (preprint of a paper presented during scientific conference "Educational Research and Educational Policy"), Warszawa, PTP-IRWIR.

Nowakowska-Siuta, R., Śliwerski, B. (2015). Racjonalność kształcenia (Rationality of Education), Kraków: Oficyna Wydawnicza "Impuls".

Popow, M. (2010). Między kolonizacją a dekolonizacją - Zadania szkoły po transformacji ustrojowej w świetle założeń pedagogiki postkolonialnej (Between Colonization and Decolonization - School Responsibilities After the Political System Transformation in the Light of Grounds of Post-colonial Pedagogy) [in:] A. Wróbel (ed.), Nauczyciel w krajach postsocjalistycznych jako sprawca i ofiara manipulacji. Studium teoretyczno-empiryczne (The Teacher in Post-communist Countries as a Perpetrator and a Victim of Manipulation. A Theoretical and Empirical Study), Łódź: Wydawnictwo UŁ.

Szahaj, A. (2014). Kapitalizm drobnego druku (Small Print Capitalism), Warszawa: Instytut Wydawniczy Książka i Prasa.

Śliwerski, A. (2010). Uwarunkowania zachowań manipulacyjnych nauczycieli. Analiza statystyczna (The Conditions of Teachers' Manipulating Behaviours. Statistical Analysis,), [in:] A. Wróbel (ed.), Nauczyciel w krajach postsocjalistycznych jako sprawca i ofiara manipulacji. Studium teoretyczno-empiryczne (The Teacher in Post-communist 
Countries as a Perpetrator and a Victim of Manipulation. A Theoretical and Empirical Study), (2010). Łódź: Wydawnictwo UŁ.

Śliwerski, B. (2013). Diagnoza uspołecznienia publicznego szkolnictwa III RP w gorsecie centralizmu (The Diagnosis of Socialization of Public Education in the Time of the 3rd Republic in the Corset of Political Centralism), Kraków: Oficyna Wydawnicza "Impuls". Śliwerski, B. (2016). Krytycznie o metodologicznych przesłankach udziału naukowców w Międzynarodowym Programie PISA/OECD (Critical Comments on Methodological Rationale of Scientists' Participation in the International PISA Survey/OECD), Studia Edukacyjne, 38, 21-42.

Wnuk-Lipiński, E. (1996). Demokratyczna rekonstrukcja z socjologii radykalnej zmiany społecznej (Democratic Reconstruction: From the Sociology of Radical Social Change), Warszawa: WN PWN .

Wróbel, A. (2006). Wychowanie a manipulacja (Education and Manipulation), Kraków: Oficyna Wydawnicza "Impuls".

Wróbel, A. (ed.) (2010). Nauczyciel w krajach postsocjalistycznych jako sprawca i ofiara manipulacji. Studium teoretyczno-empiryczne (The Teacher in Post-communist Countries as a Perpetrator and a Victim of Manipulation. A Theoretical and Empirical Study), Łódź: Wydawnictwo UŁ. 